\title{
Postharvest quality of ozonized "nanicão" cv. bananas ${ }^{1}$
}

\author{
Qualidade pós-colheita de banana cv. "nanicão" ozonizada
}

\author{
Ernandes Rodrigues de Alencar ${ }^{2 *}$, Lêda Rita D'Antonino Faroni ${ }^{3}$, Michele da Silva Pinto ${ }^{4}$, André Rodrigues da \\ Costa $^{3}$ e Tales Afonso da Silva ${ }^{3}$
}

\begin{abstract}
This study was done to analyze the physic-chemical, microbiological and sensory qualities of the banana, after being either dry or wet treatment with ozone. For dry processing, the fruits were directly fumigated with ozone for $30 \mathrm{~min}$. The wet treatment included the ozonization of water for $20 \mathrm{~min}$ followed by immersion of the fruit in the ozonized water for $10 \mathrm{~min}$. In both treatments, the utilized gas concentration and flow were $0.36 \mathrm{mg} \mathrm{L}^{-1}$ and $1.5 \mathrm{~L} \mathrm{~min}^{-1}$, respectively. The quality of the fruits was evaluated at the beginning of storage and after 3; 6; 9 and 12 days. The variables analyzed were: fresh mater loss, total titratable acidity, total soluble solids, pH, pulp/peel ratio, color index of the peel, rot severity, microbiological analysis (total fungi and yeast count) and sensorial analysis. In general, the fruits immersed in the ozonized water presented better quality, in reference to both the physico-chemical and microbiological parameters, as well as have good sensory acceptance among those tested. It could therefore be concluded that treatment with ozonized water is a new alternative for the postharvest handling of bananas.
\end{abstract}

Key words: Banana. Fruit-preservation. Food-sensorial analysis.

RESUMO - Esse trabalho teve como objetivo avaliar a qualidade físico-química, microbiológica e sensorial da banana ozonizada por via seca e por via úmida. Para o tratamento por via seca, os frutos foram fumigados diretamente com ozônio por 30 minutos. Para o tratamento da banana por via úmida, efetuou-se a ozonização da água por 20 min, e em seguida imersão dos frutos na água ozonizada por $10 \mathrm{~min}$. Em ambos os tratamentos a concentração do gás e a vazão utilizadas foram $0,36 \mathrm{mg} \mathrm{L}^{-1}$ e $1,5 \mathrm{~L} \mathrm{~min}^{-1}$, respectivamente. A qualidade dos frutos foi avaliada no início do armazenamento e aos 3; 6; 9 e 12 dias. Analisaram-se as variáveis: perda de massa fresca (PMF), acidez total titulável, sólidos solúveis totais, $\mathrm{pH}$, relação polpa/casca, índice de cor da casca, severidade de podridões, análise microbiológica (contagem total de fungos e leveduras) e análise sensorial. Em geral, os frutos imersos em água ozonizada foram os que apresentaram melhor qualidade ao longo do armazenamento, tanto no que se refere aos parâmetros físico-químicos quanto aos microbiológicos, e tiveram boa aceitação sensorial entre os provadores. Dessa forma, concluiu-se que o tratamento com água ozonizada é uma nova alternativa para manejo pós-colheita de banana.

Palavras-chave: Banana. Frutas-conservação. Alimentos-análise sensorial.

\footnotetext{
* Autor para correspondência

${ }^{1}$ Recebido para publicação em 14/04/2010; aprovado em 15/07/2012

Pesquisa Financiada pelo CNPq

${ }^{2}$ Faculdade de Agronomia e Medicina Veterinária, Universidade de Brasília/UnB, Brasília-DF, Brasil, 70.910-900, ernandesalencar@unb.br ${ }^{3}$ Departamento de Engenharia Agrícola, Universidade Federal de Viçosa/UFV, Viçosa-MG, Brasil, 36.570-000, 1faroni@ufv.br, ardcosta@yahoo.com. br, tasilva@yahoo.com.br

${ }^{4}$ Departamento de Tecnologia de Alimentos, Universidade Federal de Viçosa/UFV, Viçosa-MG, Brasil, 36.570-000, mimenorddd@ yahoo.com.br
} 


\section{INTRODUCTION}

The banana is characterized as a flavorful and nutritive fruit, being an excellent source of carbohydrates, fiber, potassium and vitamins (ENGLBERGER et al., 2003; FORSTER et al., 2002). According to Arruda et al. (2007), banana is the second most popular fruit in Brazil.

World banana production in 2010 was 102 million tons, principally origination from the countries of India, China, Philippines, Equator, and Brazil (FAO, 2012). Despite being one of the largest banana producers in the world, Brazil exports little and its participation on the international market is approximately $0.5 \%$. This is due to the fact that the majority of national production is destined for the internal market (BARROS; PIZZOL, 2001). However, according to Pizzol and Eleutério (2000), even though there is no excess of bananas for exportation, the produced fruits do not possess the demanded quality to conquer the external market, principally due to the precarious production structure and commercialization methods predominant in Brazil. To change this situation, policies and technologies which improve the current production, harvest and postharvest conditions of the product are necessary.

In banana postharvest, one of the principal problems encountered is related to fungal attack, which depreciates fruit quality making it inadequate for commercialization on the international level. Moraes et al. (2006) confirmed that pathogen establishment on the banana can occur of different forms: quiescent infection, bruising or during pre-harvest. According to Bastos and Albuquerque (2004), anthracnose is one of the principal postharvest pathogens in bananas, caused by the fungus Colletotrichum musae (Berk and Curtis) Arx. Chemical treatments with fungicides have been used against this disease with the objective of reducing the quantity of inoculate in the field. However, the presence of chemical residues in agricultural products and its accumulation in the environment has attracted interest of the public and authorities and has stimulated researches for alternative methods of postharvest disease control (MARI; GUIZZARDI, 1998), including the use of ozone.

Ozone is highly reactive with a half-life ranging from 15 to 30 minutes, degraded into $\mathrm{O}_{2}$ which presents no residual activity. The half-life of ozone in distilled water at $20{ }^{\circ} \mathrm{C}$ is generally considered to be 20 to $30 \mathrm{~min}$ (CULLEN et al., 2009; KHADRE et al., 2001). Ozonization has been suggested as an effective antimicrobial sanitizer for water, food, and food processing surfaces and equipment (NOVAK; YUAN, 2007; SAPERS, 2001). In 2001, the U.S. Food Drug Administration (FDA) approved the use of ozone as an antimicrobial agent in the treatment, storage, and processing of meats and produce. Exposure time necessary for elimination of microorganisms depends on the microbial species and the $\mathrm{O}_{3}$ concentration; a concentration less than $0.02 \mathrm{mg} \mathrm{L}^{-1}$ is sufficient for water purification. The gas acts directly on the surface of the microorganisms and destroys its cell wall (STUCKI et al., 2005; SUSLOW, 2004). In literature there are several reports that describe the ozone effect on microorganisms, among which, fungi of genera Aspergillus, Fusarium, Geotrichum, Myrothecium, Alternaria and Mucor (RAILA et al., 2006; WU et al., 2006; ZOTTI et al., 2008), in addition to virus, protozoans and bacteria (AGUAYO et al., 2006; KHADRE et al., 2001; WHANGCHAI et al., 2006). Ozone was effective as post-harvest fruits such as grape, persimmon, and longan fruit (CAYUELA et al., 2009; GABLER et al., 2009; SALVADOR et al., 2006; WHANGCHAI et al., 2005). Therefore, the objective of this work was to evaluate the physical-chemical, microbiology and sensorial quality of the cv. "Nanicao" banana treated with ozone and either applied dry or wet.

\section{MATERIAL AND METHODS}

This study was performed in the Laboratory for Pre-Processing and Storage of Agricultural Products of the Agricultural Engineering Department and the Packaging and in the Sensorial Analysis Laboratories of the Food Engineering Department, both of the Universidade Federal de Viçosa (UFV), located in Viçosa, MG, Brazil.

Bananas of the "Nanicao" variety grown at the Pomar Fundão of the Plant Science Department, UFV were used. The fruits were treated with ozone by either dry (direct ozonization) or wet (fruits were immersed in ozonized water) application methods.

For the dry application treatment, the previously selected fruits were added to a plastic recipient with a volume of $6.0 \mathrm{~L}$. The product was then fumigated with $\mathrm{O}_{3}$ for 30 minutes. For treatment via wet application, water was initially ozonized for 20 minutes in a cylindrical glass recipient with a capacity of $3.2 \mathrm{~L}$. The previously selected fruits were then immersed in the ozonized water where they remained for 10 minutes. Gas concentration in the utilized treatments was $0.36 \mathrm{mg} \mathrm{L}^{-1}$ and $1.5 \mathrm{~L} \mathrm{~min}^{-1}$, respectively.

Ozone gas was obtained by means of an ozone generator based on dielectric barrier discharge (DBD) developed by the Department of Physics at the Aeronautical Institute of Technology, São José dos Campos, SP, Brazil. In the ozone generation process, humidity free oxygen was used as an input. Bananas untreated with ozone were used as an experimental control. After the treatments, the bananas were stored in BOD chambers at $25 \pm 2{ }^{\circ} \mathrm{C}$ and 
relative humidity of $75-85 \%$ for 12 days. Banana quality was evaluated on the day of storage and after $3 ; 6 ; 9$ and 12 days. The variables analyzed were: fresh mater loss (FML), total titratable acidity (TTA), total soluble solids (TSS), $\mathrm{pH}$, pulp/peel ratio (PP), color index of the peel, rot severity, microbiological analysis (total fungi and yeast count) and sensorial analysis.

Fresh matter loss was determined by the difference between the initial fresh mass and final mass after each storage period and is expressed as a percentage. Total titratable acidity was calculated by titrometry, in which performed titration conformed to the methodology described by Instituto Adolfo Lutz (IAL, 2005) and results were expressed in percentage of fresh pulp, considering malic acid to be predominant. The $\mathrm{pH}$ was determined with a digital PH meter (W3B Model, Bel Engineering) and total soluble solids were determined by refractometry (ELine 90 Model, Bellingham Stanley Ltd.) and expressed in ${ }^{\circ}$ Brix. The pulp/peel ratio was obtained by dividing the weight of the fruit pulp by the weight of the peel. For evaluation of the peel color index (ripening stages), a visual analysis of the color of each experimental unit was done and classified according to the methodology proposed by Von Loesecke, modified by Lii et al. (1982), on a scale of 9 ripening stages where 1 corresponds to green fruits which were not exposed to gas treatment to accelerate ripening and 9 to the yellow bananas with many brown spots. Lesioned area was resolved with the help of a diagrammatic scale proposed by Moraes et al. (2006), with variations from 0 to $64 \%$ of the injured fruit area.

Microbial analyses of the banana peel were performed by the surface plaque assay method, where each sample was properly diluted in peptonated water $(0.1 \%)$. Filamentous fungi and yeast quantification was performed using the PDA medium (Potato Dextrose Agar) acidified with tartaric acid at $10 \%$. The plaques were incubated at $25^{\circ} \mathrm{C}$ for 3-5 days and the results expressed in $\mathrm{CFU} \mathrm{mL} \mathrm{m}^{-1}$.

In the sensorial analysis, performed on the eighth day of storage, acceptability of the ozonized bananas was evaluated by individuals with ages from 15 to 50 . Three banana samples, corresponding to each treatment (control, dry ozonization and wet ozonization), were presented in a single session and the evaluators analyzed the external appearance of the fruits. Later, in individual booths, three banana slices were serves, one from each treatment, for evaluation of flavor and texture of the samples. Using a hedonic scale of nine points (1 - strong dislike and 9-strong liking), the evaluators indicated how much they liked or disliked each attribute. The evaluators also responded to questions regarding purchase of the product, utilizing a five point scale: ( 1 - certainly would not consume to 5 - certainly would consume). It was also solicited that questions be answered about criteria used for product selection.
The experiment setup was of a completely randomized design and each treatment consisted for three replications. Initially, a variance analysis in the Saeg 9.1 (Statistical Analysis System) system was done, followed by an analysis of regression for the FML and Tukey test for the TTA, TSS, $\mathrm{pH}, \mathrm{PP}$ and sensorial analysis. The SigmaPlot 2001 software (SPSS Science, Chicago, USA) was used to produce all graphs.

\section{RESULTS AND DISCUSSION}

It was observed significant increase of fresh matter loss of banana for all treatments during the stored period (Figure 1 and Table 1). For the bananas treated directly with ozone gas, an accentuated increase in fresh mater loss was observed after nine days and this can be explained by damages to the epidermis caused by the ozone at the utilized concentration, due to its strong oxidizing potential (CRISOSTO et al., 1993; SELMA et al., 2008). In relation to the bananas immersed in ozonized water, a smaller loss was detected during the entire storage period. After 12 days, a fresh matter loss of less than $10 \%$ was observed, suggesting that this treatment does not damage the banana and reduces quantitative deterioration. Loss of fresh mater in the non-ozonized banana (control) was greater than in the treated fruits with ozonized water. After nine days, a fresh mater loss of more than $10 \%$ was observed, which according to Chitarra and Chitarra (2005), is the allowable limit in order for the product to be commercialized. This loss is related to water which is found in greater concentrations in green bananas, but during the ripening phases, water content tends to fall due to transpiration increases.

Figure 1 - Fresh matter loss (FML) of the banana treated with ozone and stored at $25^{\circ} \mathrm{C}$ for 12 days, Viçosa, 2008

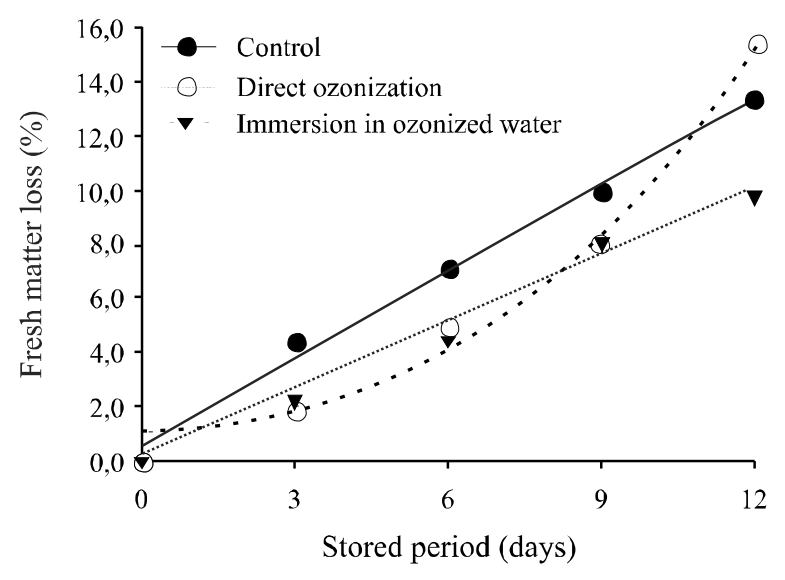


Table 1 - Analysis of variance for fresh matter loss (FML), total soluble solids (TSS), pH, total titratable acidity (TTA) and pulp/peel ration of banana treated with ozone and stored at $25^{\circ} \mathrm{C}$ for 12 days

\begin{tabular}{lcccccc}
\hline \multirow{2}{*}{ Source of Variation } & \multirow{2}{*}{ Degree of Freedom } & \multicolumn{5}{c}{ Mean Squares } \\
\cline { 3 - 6 } & & FML & TSS & pH & TTA & PP \\
\hline Treatment (T) & 2 & $16.987^{*}$ & $1.825^{*}$ & $0.161 \mathrm{E}-03^{\text {ns }}$ & $0.840^{\text {ns }}$ & $0.556^{\text {ns }}$ \\
Stored Period (SP) & 4 & $181.503^{* *}$ & $322.210^{* *}$ & $1.393^{* *}$ & $0.109^{* *}$ & $1.592^{* *}$ \\
T x SP & 8 & $141.964^{* *}$ & $1.097^{*}$ & $0.193 \mathrm{E}-01^{* *}$ & $0.420^{\text {ns }}$ & $0.193^{\text {ns }}$ \\
Residuals & 30 & 6.291 & 0.428 & $0.395 \mathrm{E}-02$ & 0.246 & 0.239 \\
CV $(\%)$ & & 45.546 & 3.039 & 1.217 & 5.742 & 26.988 \\
\hline
\end{tabular}

${ }_{\text {ns }}$ No-significant; *Significant at $5 \% ; * *$ Significant at $1 \%$

The adjusted equations for linear regression and their respective determination coefficients are shown in Table 2, which relate the banana fresh material loss to its storage period.

Table 2 - Regression equations for fresh mater loss of bananas treated with ozone and stored at $25^{\circ} \mathrm{C}$ for 12 days, Viçosa, 2008

\begin{tabular}{lcc}
\hline \multicolumn{1}{c}{ Treatment } & Adjusted equations & $\mathrm{r}^{2}$ \\
\hline Control & $\hat{\mathrm{y}}=0.51+1.08 * * \mathrm{X}$ & 0.99 \\
Direct ozonization & $\hat{\mathrm{y}}=\mathrm{e}^{(0.23 \mathrm{X})}$ & 0.98 \\
Immersion in ozonized & $\hat{\mathrm{y}}=-0.17+0.82 * * \mathrm{X}$ & 0.99 \\
water & & \\
\hline
\end{tabular}

** Significant at $1 \%$

It was verified that total soluble solids differed significantly among samples due to the interaction between ozone treatment and storage period (Table 1). Values for average total soluble solids are shown in Table 3 for the bananas treated without and with ozone gas and stored at $25^{\circ} \mathrm{C}$ for 12 days. It was also observed that the bananas treated directly with gas presented lower total soluble solid values after 12 days in comparison with the other treatments. It should be mentioned that the increase in total soluble solids in the banana during storage is caused by the hydrolysis of starch into sugars, increasing the concentration of sucrose, glucose and fructose in the banana pulp, while the decrease of this variable is associated with the senescence of the product (LUCENA et al., 2004).

The $\mathrm{pH}$ differed significantly among samples due to the interaction between ozone treatment and storage period (Table 1). Decreases in $\mathrm{pH}$ were verified for all treatments until the third day of storage and then they increased (Table 4). This behavior is in accordance with Silva et al. (2006) who affirmed that $\mathrm{pH}$ diminished after banana harvest and increases at the end of its ripening or onset of senescence. Increase may be related to the hydrolysis of starch into reducing sugars and conversion into pyruvic acid, which is oxidized in the Krebs cycle during fruit respiration (CHITARRA; CHITARRA, 2005). On the sixth and ninth day of storage, the lowest $\mathrm{pH}$ value was observed for directly ozonized fruit. However, on the twelfth day, the fruits treated directly with ozone gas were those which showed the lowest $\mathrm{pH}$ values; the low $\mathrm{pH}$ values are associated with greater degrees of senescence.

No significant difference $(\mathrm{p}<0.05)$ for total titratable acidity and the pulp/peel ratio were observed in function of the ozone treatment during the stored

Table 3 - Average values for total soluble solids of the bananas treated with ozone and stored at $25^{\circ} \mathrm{C}$ for 12 days, Viçosa, 2008

\begin{tabular}{lccccc}
\hline \multirow{2}{*}{ Treatment } & \multicolumn{5}{c}{ Storage period (days) } \\
\cline { 2 - 6 } & 0 & 3 & 6 & 9 & 12 \\
\hline Control & $15.8 \mathrm{aC}$ & $25.3 \mathrm{aA}$ & $24.1 \mathrm{aA}$ & $22.1 \mathrm{aB}$ & $21.0 \mathrm{aB}$ \\
Direct ozonization & $15.8 \mathrm{aD}$ & $24.2 \mathrm{aA}$ & $24.6 \mathrm{aA}$ & $22.1 \mathrm{aB}$ & $19.8 \mathrm{bC}$ \\
Immersion in ozonized water & $15.8 \mathrm{aD}$ & $25.1 \mathrm{aA}$ & $25.7 \mathrm{aA}$ & $22.1 \mathrm{aB}$ & $20.7 \mathrm{aC}$ \\
\hline
\end{tabular}

Values followed by the same lower-case letter in the column do not differ among themselves by the Tukey test (p<0.05); Values followed by the same upper-case letter in the line do not differ among themselves by the Tukey test $(\mathrm{p}<0.05)$ 
Table 4 - Average $\mathrm{pH}$ value of the bananas treated with ozone and stored at $25^{\circ} \mathrm{C}$ for 12 days, Viçosa, 2008

\begin{tabular}{lccccc}
\hline \multirow{2}{*}{ Treatment } & \multicolumn{5}{c}{ Storage period (days) } \\
\cline { 2 - 6 } & 0 & 3 & 6 & 9 & 12 \\
\hline Control & $5.18 \mathrm{aC}$ & $4.84 \mathrm{aE}$ & $5.08 \mathrm{aD}$ & $5.56 \mathrm{aB}$ & $5.79 \mathrm{bA}$ \\
Direct ozonization & $5.18 \mathrm{aC}$ & $4.86 \mathrm{aD}$ & $4.96 \mathrm{bD}$ & $5.50 \mathrm{bB}$ & $5.93 \mathrm{aA}$ \\
Immersion in ozonized water & $5.18 \mathrm{aC}$ & $4.88 \mathrm{aD}$ & $5.14 \mathrm{aC}$ & $5.59 \mathrm{aB}$ & $5.75 \mathrm{bA}$ \\
\hline
\end{tabular}

Values followed by the same lower-case letter in the column do not differ among themselves by the Tukey test $(\mathrm{p}<0.05)$; Values followed by the same upper-case letter in the line do not differ among themselves by the Tukey test $(\mathrm{p}<0.05)$

period according to the variance analysis (Table 1). It was verified that, independently of the ozone treatment, there was an increase in the total titratable acidity until the third day, with an average values of $0.43 \%$, and soon after began it to decrease, reaching a final average value of $0.14 \%$ at the end of the storage period. According to Carvalho et al. (1989) and Silva et al. (2006), total titratable acidity for banana increases with its ripening and decreases when the fruit is either very ripe or in senescence. Referring to the pulp/peel ration, increases in all three treatments was observed, independently of the ozone treatment, and the variation range between these parameters during storage was from 1.26 to 2.63 . This phenomenon is denominated by transpiration and osmatic losses of water from the peel (VILLAS-BOAS et al., 1996).

Ripening stages of the banana treated with ozone are presented in Table 5. It was observed that only bananas treated directly with ozone were classified as being in stage 6 (yellow fruits with green spots) on the sixth day of storage. The fruits of the control treatment and those immersed in ozonized water were classified as stage 8 (yellow fruits with small brown spots) on the sixth day of storage. However, on the twelfth day, the fruits from the control and those treated directly with gas were classified as stage 9 (yellow fruits with large brown spots) while those immersed in ozonized water were classified at stage 8 .
Figure 2 shows the evolution of the lesioned area of the banana treated with ozone and stored at $25^{\circ} \mathrm{C}$ for 12 days. Percentage of the fruit lesioned area was affected by the ozone treatment, being that during the nine day storage period, $4 \%$ of the total area of the ozone treated fruit was lesioned and $16 \%$ of the untreated fruit. After 12 days of storage, the bananas immersed in ozonized water showed $8 \%$ bruising while the untreated fruits showed $32 \%$ bruising. However, in the fruits treated directly with gas, the percentage of the lesioned area was equal to that of the untreated fruit after 12 days of storage. The presence of brown spots makes the product less attractive and therefore, less suitable for commercialization (CHITARRA; CHITARRA, 2005). The observed brown spots are characteristic of anthracnose, considered the most severe postharvest disease to bananas, caused by the fungus Colletotrichum musae (CORDEIRO et al., 2004).

In relation to the total fungi and yeast count in the banana peel either untreated or treated with ozone, it was observed that after 12 days of storage, lower counts were registered in fruits treated with ozonized water $\left(6.1 \times 10^{2} \mathrm{UFC} \mathrm{g}^{-1}\right)$ in relation to the control which presented an equivalent count of $6.1 \times 10^{3} \mathrm{UFC}^{-1}$. On the other hand, in the directly ozonized fruits, an even greater fungi and yeast count was observed $\left(2.5 \times 10^{5} \mathrm{UFC}^{-1}\right)$. This can be explained by the possibility that the directly applied ozone at the concentration of $0.36 \mathrm{mg} \mathrm{L}^{-1}$ caused damage to the fruit epidermis, due to the high oxidant

Table 5 - Ripening states of bananas in accordance with the degree of coloration of the banana peel treated with ozone and stored at $25^{\circ} \mathrm{C}$ for 12 days, Viçosa, 2008

\begin{tabular}{lllllc}
\hline \multicolumn{1}{c}{ Treatment } & \multicolumn{5}{c}{ Storage period (days) } \\
\cline { 2 - 6 } & 0 & 3 & 6 & 9 & 12 \\
\hline Control & 2 & 4 & 7 & 7 & 8 \\
Direct ozonization & 2 & 4 & 5 & 7 & 8 \\
Immersion in ozonized water & 2 & 4 & 7 & 7 & 7 \\
\hline
\end{tabular}

1 - Green fruits which were not exposed to gas treatment to accelerate ripening; 2 - Green; 3 - Green/a trace of yellow; 4 - More green than yellow;

5 - More yellow than green; 6 - Yellow with a green tip; 7 - All yellow; 8 - Yellow/a few brown spots; 9 - Yellow/many brown spots 
Figure 2 - Evolution of the lesioned area of the banana treated with ozone and stored at $25{ }^{\circ} \mathrm{C}$ for 12 days, Viçosa, 2008

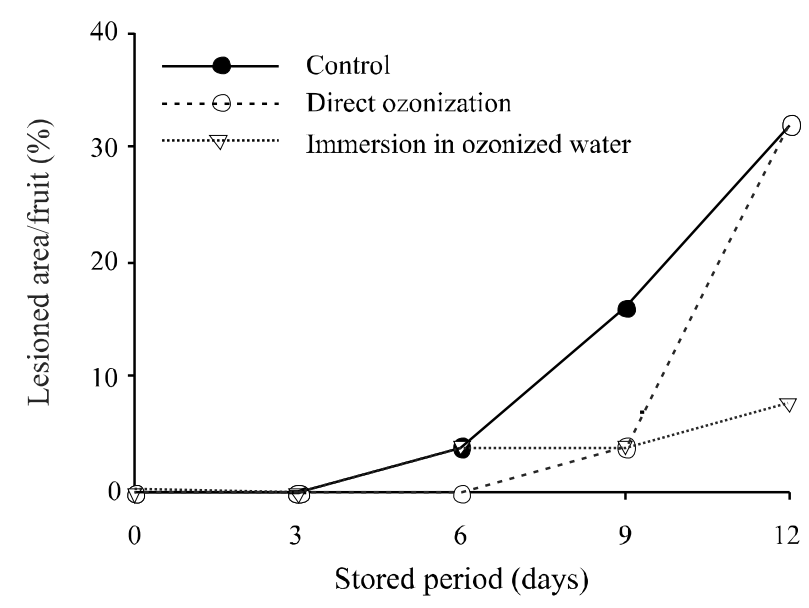

potential of ozone. Therefore, this treatment makes the fruits more susceptible to pathogen attack and development (BRACKMANN et al., 1999). This confirms the behavior observed for fresh matter lass (Figure 1) in the fruits treated directly with ozone. On the twelfth day of storage, these fruits showed greater FML values, which may be attribute to microbiological contamination. According to Chitarra and Chitarra (2005), attack by microorganisms, such as fungi, is one of the most serious losses both qualitatively and quantitatively during fruit postharvest.
It is important to restate that at the beginning of storage and after six days no microorganism presence was detected. This may be explained by the fact that potential infection observed on the banana is cause by anthracnose, quiescent and initiated in the field, caused by spores dispersed in the air, reach and infect the fruits. However, no infection symptoms are observed in the green bananas, remaining pathologically quiescent until the beginning of ripening (CORDEIRO et al., 2004).

Acceptance results indicated that, for the flavor attribute no significant difference was observed (Table 6 and Table 7), found between the hedonic terms 6 (slightly liked) and 8 (really liked). Significant difference was observed in relation to textural and appearance attributes as a results of the type of ozone application (Table 6 and Table 7). For the texture attribute, the control fruit and those immersed in ozonized water produced an equal hedonic acceptance of 7 (lightly liked). Appearance of bananas treated directly with ozone differed statistically from the control bananas and those treated with ozonized water. The hedonic rating corresponding to the dry ozone treatment was situated between 5 (neither liked nor disliked) and 6 (lightly liked), while the control bananas and those treated with ozonized water were situated between 6 and 7 . It should be mentioned that $43 \%$ of the evaluators used appearance as the criteria for buying the product.

Table 6 - Analysis of variance for flavor, texture, appearance and intention to buy attributed of bananas treated with ozone on the eighth day of storage

\begin{tabular}{lccccc}
\hline \multirow{2}{*}{ Source of Variation } & \multirow{2}{*}{ Degree of Freedom } & \multicolumn{4}{c}{ Mean Squares } \\
\cline { 3 - 6 } & & Flavor & Texture & Appearance & Intention to buy \\
\hline Treatment $(\mathrm{T})$ & 2 & $7.269^{\mathrm{ns}}$ & $10.488^{*}$ & $36.869^{* *}$ & $15.353^{* *}$ \\
Residuals & 288 & 2.725 & 2.702 & 2.489 & 1.222 \\
$\mathrm{CV}(\%)$ & & 24.327 & 24.259 & 24.306 & 31.604 \\
\hline
\end{tabular}

${ }_{\text {ns }}$ No-significant; *Significant at $5 \%$;* Significant at $1 \%$

Table 7 - Average of flavor, texture, appearance and intention to buy attributed of bananas treated with ozone on the eighth day of storage

\begin{tabular}{lcccc}
\hline \multirow{2}{*}{ Treatment } & \multicolumn{3}{c}{ Attributes } \\
\cline { 2 - 5 } & Flavor & Texture & Appearance & Intention to buy \\
\hline Control & 7.1 & $6.9 \mathrm{ab}$ & $6.6 \mathrm{a}$ & $3.6 \mathrm{a}$ \\
Direct ozonization & 6.3 & $6.4 \mathrm{~b}$ & $5.8 \mathrm{~b}$ & $3.1 \mathrm{~b}$ \\
Immersion in ozonized water & 6.8 & $7.0 \mathrm{a}$ & $7.0 \mathrm{a}$ & $3.8 \mathrm{a}$ \\
\hline
\end{tabular}

Values followed by the same lower-case letter in the column do not differ among themselves by the Tukey test $(\mathrm{p}<0.05)$ 
There was a significant difference for intention to buy bananas (Table 6 and Table 7), in which a lower buying intention was observed for the fruits treated directly with ozone. At least $72 \%$ of evaluators probably or certainly would consume bananas treated with ozonized water, while for bananas treated directly with gas this number fell to less than $50 \%$.

\section{CONCLUSIONS}

1. Treatment with ozonized water is a new alternative for postharvest management of bananas since it retards the evolution of fungal infections, reduces the fresh mater loss and retards the decrease of total soluble solids, as well as present good sensorial acceptance among evaluators;

2. For banana treatment directly with ozone gas, it is necessary to optimize concentration and exposure time so that the gas does not damage the fruits. In this case, satisfactory results were observed up to nine days of storage.

\section{REFERENCES}

AGUAYO, E.; ESCALONA, V. H.; ARTES, F. Effect of cyclic exposure to ozone gas on physicochemical, sensorial and microbial quality of whole and sliced tomatoes. Postharvest Biology and Technology, v. 39, p. 169-177, 2006.

ARRUDA, A. R. et al. Caracterização físico-química e avaliação sensorial de bebida fermentada alcoólica de banana. Revista Ciência. Agronômica, v. 38, n. 04, p. 377 384, 2007.

BARROS, E. M.; PIZZOL, S. J. S. Comércio internacional de banana. Preços Agrícolas, v. 173, p. 28-29, 2001.

BAstos, C. N.; AlBUQUeRQUE, P. S. B. Efeito do óleo de Piper aduncum no controle em pós-colheita de Colletotrichum musae em banana. Fitopatologia Brasileira, v. 29 , n. 05 , p. 555-557, 2004.

BRACKMANN, A.; LUNARDI, R.; DONAZZOLO, J. Frigoconservação e controle de podridões em laranja 'Valência'. Ciência Rural, v. 29, n. 02, p. 247-251, 1999.

CARVALHO, H. A.; CHITARRA, M. I. F.; CARVALHO, H. S. Qualidade de banana 'Prata' previamente armazenada em filme de polietileno, amadurecida em ambiente com umidade relativa elevada. Pesquisa Agropecuária Brasileira, v. 24 (5), p. 495-501, 1989.

CAYUELA, J.A. et al. Control of Table Grapes Postharvest Decay by Ozone Treatment and Resveratrol Induction. Food Science and Technology International, v. 15, p. 495-502, 2009.
Chitarra, M. I.; Chitarra, A. B. Pós-colheita de frutos e hortaliças; fisiologia e manuseio. Lavras: Editora UFLA, 2005. 785 p.

CORDEIRO, Z. J. M.; MATOS, A. P.; MEISSNER FILHO, P. E. Doenças e métodos de controle, In: BORGES, A. L.; SOUZA, L. S. O cultivo da bananeira Cruz das Almas: Nova Civilização, 2004. p.146-182.

CRISOSTO, C. H. et al. Postharvest performance evaluation of plum (Prunus salicina Lindel., 'Casselman') fruit grown under three ozone concentrations. Journal of the American Society for Horticultural Science, v. 118, n. 04, p. 497-502, 1993.

CULLEN, P. J. et al. Modelling approaches to ozone processing of liquid foods. Trends in Food Science \& Technology, v. 20, p. 125-136, 2009.

ENGLBERGER, L. et al. Further analyses on micronesian banana, taro, breadfruit and other foods for provitamin A carotenoids and minerals. Journal of Food Composition and Analysis, v. 16, p. 219-236, 2003.

FAO. Food and Agriculture Organization of the United Nations. Food and Agricultural commodities production, 2012. Available at: < http://faostat.fao.org/>. Retrieved Jan 15, 2012, from Faostat Database.

FORSTER, M. P.; RODRIÄGUEZ, E. R.; ROMERO, C. D. Differential characteristics in the chemical composition of bananas from Tenerife (Canary Islands) and Ecuador. Journal of Agricultural and Food Chemistry, v. 50, p. 7586-7592, 2002.

GABLER, F. M. et al. Influence of fumigation with high concentrations of ozone gas on postharvest gray mold and fungicide residues on table grapes. Postharvest Biology and Technology, v. 55, p. 85-90, 2010.

IAL. Instituto Adolfo Lutz. Métodos físico-químicos para análise de alimentos. Brasília: Editora ANVISA, 2005. 1018 p.

KHADRE, M. A.; YOUSEF, A. E.; KIM, J. G. Microbiological Aspects of Ozone Applications in Food: A Review. Journal of Food Science, v. 66, n. 09, p. 1242-1252, 2001.

LII, C. Y.; CHANG, S. M.; YOUNG, Y. L. Investigation of the physical and chemistry properties of banana starches. Journal of Food Science, v. 47, p. 1493-1497, 1982.

LUCENA, C. C. et al. Efeito da película de amido na conservação pós-colheita de frutos de banana cv. "Nanicão". Agronomia, v. 38, n. 02, p.34-37, 2004.

MARI, M.; GUIZZARDI, M. The postharvest phase: emerging technologies for the control of fungal diseases. Phytoparasitica, v. 01, n. 26, p. 59-66, 1998.

MORAES, W. S.; ZAMBOLIM, L.; LIMA, J. D. Incidência de fungos em pós-colheita de banana 'Prata anã'(Musa AAB). Summa phytopathologica, v. 32, n. 01, p. 67-70, 2006.

NOVAK, J. S.; YUAN, T. C. The ozonation concept: Advantages of ozone treatment and commercial developments. In: TEWARI, G.; JUNEJA, V.K. Advances in thermal and non-thermal food preservation Ames: Blackwell Publishing, 2007. p.185-193. 
PIZZOL, S. J. S.; ELEUTÉRIO, R. C. Fruticultura: participação do Brasil no mercado externo de bananas. Preços Agrícolas, v. 14, n. 162, p. 40-41, 2000.

RAILA, A. et al. Application of ozone for reduction of mycological infection in wheat grain. Annals of Agricultural and Environmental Medicine, v. 13, n. 02, p. 287-294, 2006.

SALVADOR A. et al. Effect of ozone on postharvest quality of persimmon. Journal of Food Science, v. 71, n. 06, p. S443-S446, 2006.

SAPERS, G. M. Efficacy of washing and sanitizing methods for disinfection of fresh fruit and vegetable products. Food Technology and Biotechnology, v. 39, n. 04, p. 305-311, 2001.

SELMA, M. V. et al. Effect of gaseous ozone and hot water on microbial and sensory quality of cantaloupe and potential transference of Escherichia coli O157:H7 during cutting. Food Microbiology, v. 25, p. 162-168, 2008.

SILVA, C. S. et al. Amadurecimento da banana-prata climatizada em diferentes dias após a colheita. Ciência e Agrotecnologia, v. 30, p. 01, p. 103-111, 2006.

STUCKI, S. et al. Ozonization of purified water systems. Pharmaceutical Engineering, v. 25, n. 01, p. 40-56, 2005.
SUSLOW, T. V. Ozone applications for postharvest disinfection of edible horticultural crops. Oakland: Division of Agriculture and Natural Resources, University of California, 2004. Publication 8133,8 p.

VILAS-BOAS, E. V. B.; CHITARRA, A. B.; CHITARRA, M. I. F. Modificações pós-colheita de banana "prata" irradiada. Pesquisa Agropecuária Brasileira, v. 31, n. 09, p. 599-607, 1996.

WHANGCHAI, K.; SAENGNIL, K.; UTHAIBUTRA, J. Effect of ozone in combination with some organic acids on the control of postharvest decay and pericarp browning of longan fruit. Crop Protection, v. 25, p. 821-825, 2006.

WHANGCHAI, K.; SAENGNIL, K; UTHAIBUTRA, J. Control of postharvest diseases in longan fruit by ozone. In: V International Postharvest Symposium, 5., Verona, Italy. Proceedings... Verona: ISHS, 2005. p. 2121-2126.

WU, J.; DOAN, H.; CUENCA, M. A. Investigation of gaseous ozone as an anti-fungal fumigant for stored wheat. Journal of Chemical Technology \& Biotechnology, v. 81, n. 07, p. 1288-1293, 2006.

ZOTTI, M. et al. Inactivation of Aspergillus spp. by ozone treatment. Ozone-Science \& Engineering, v. 30, n. 06, p. 423-430, 2008. 